\title{
Seroprevalence Rates of Hepatitis B Surface Antigen, Anti- Hepatitis C Virus and Anti-Human Immunodeficiency Virus $1 / 2$ Certain Risk Groups
}

\author{
Belirli Risk Gruplarında Hepatit B Yüzey Antijeni, Anti-Hepatit C Virüsü ve Anti-Insan Immün \\ Yetmezlik Virüsü $1 / 2$ Seroprevelans Oranları
}

\author{
Tayfur DEMIRAY1, Kerem YILMAZ², Mehmet KÖROĞLU2', Mustafa ALTINDIŞ2 \\ 1Sakarya University Training and Research Hospital, Clinic of Clinical Microbiology Laboratory, Sakarya, Turkey \\ 2Sakarya University Faculty of Medicine, Department of Medical Microbiology, Sakarya, Turkey
}

Keywords: Hepatitis B surface antigen, anti-hepatitis $C$ virus, anti-human immunodeficiency virus $1 / 2$, seroprevelance, risk groups

Anahtar Kelimeler: Hepatit B yüzey antijeni, anti-hepatit C virüsü, anti-insan immün yetmezlik virüsü 1 ², seroprevelans, risk grupları

Demiray T, Yılmaz K, Köroğlu M, Altındiș M. Seroprevalence Rates of Hepatitis B Surface Antigen, Anti-Hepatitis C Virus and Anti-Human Immunodeficiency Virus $1 / 2$ Certain Risk Groups. Viral Hepat J 2016;22:65-66

\section{Dear Editor;}

Hepatitis B virus (HBV), hepatitis C virus (HCV) and human immunodeficiency virus (HIV) are the causes of serious viral infections affecting millions of people worldwide. Every aspect of the issue, such as modes of transmission, laboratory detection, treatment, economical burden of the diseases, etc., is one of the major concerns of the modern medicine. Diabetics, pregnant women, hemodialysis patients and cancer patients constitute high-risk groups for exposure to these infections and chronicity due to impaired or decreased immune systems, high proportion of interventional procedures, parenteral treatments and transfusions (1). It is obvious that development of the above mentioned viral infections in these immunocompromised patients also may result in more serious clinical presentations and may increase the risk for chronic infections compared to the normal population. Tracking of seroprevelance rates of viral agents provides the necessary epidemiologic data for the health-care providers together with the patients and their relatives about these infections. In this retrospective study, we have aimed to evaluate the seroprevelance rates in high-risk patients and to improve awareness of prone population on both sides of the health service.
We have determined the levels of serum hepatitis B surface antigen (HBsAg), anti-HCV and, anti-HIV $1 / 2$ by chemiluminescence microparticle immunoassay method (i1000/2000, Abbott, USA) in high-risk populations during a one-year period between March 2015 and March 2016 to determine the seroprevalence rates of HBV, HCV and, HIV. S/Co levels of $<0.9$ were accepted as negative and $\mathrm{S} / \mathrm{Co}$ levels of $\geq 1.1$ were accepted as positive. Serum samples with a S/Co value between 0.9 and 1.1 were assigned as borderline; such samples were retested and evaluated accordingly. Seroprevalence rates of HBV, HCV and HIV are listed in the Table 1.

We have figured out that HBsAg seropositivity was below the average among cancer patients, hemodialysis patients and pregnant women compared to the other studies concerning the high-risk populations in our country, however, HBsAg seropositivity in diabetic patients was higher than the average of the studies $(2,3,4,5)$. Diabetic patients use pocket glucose measurement devices and insulin injectors throughout their lives. These procedures possess risk of transmission of viral infections via repeated use of disposable instruments and sharing these devices and injectors with others. These patients should be educated in terms of transmission of viruses together with other infectious agents and should be warned not to share personal devices. 
Serum anti-HCV levels were also found to be below the average in hemodialysis patients, pregnant women and diabetics. Anti-HCV seroprevelance in cancer patients were similar to the rates reported in similar studies in our country $(2,3,4,5)$.

Although not as common as HBV and HCV infections in our country -but increasing at worrying rate-, anti-HIV $1 / 2$ were detected as compatible with data from other such studies, except for pregnant women, among whom Anti-HIV $1 / 2$ seroprevalence rates were low $(2,3,4,5)$.

Tracking serotrends for infectious viral agents especially in high risk-groups is important, not only for epidemiological purposes but also purposing appropriate vaccination policies, infection control procedures and early diagnosis of the diseases. Preventive measures should include safe medical interventions together with education of the patients and relatives. By this way, health-care providers may also have increased awareness to protect themselves from iatrogenic transmissions of such contiguous viral agents.

Table 1. Seroprevelance rates of hepatitis B virus, hepatitis $C$ virus and human immunodeficiency virus in high-risk patient groups

\begin{tabular}{|l|l|l|l|l|}
\hline \multicolumn{2}{|c|}{} & \multicolumn{3}{|l|}{ Seropositivity rates } \\
\hline \multicolumn{2}{|l|}{ Risk groups } & HBsAg & Anti-HCV & Anti-HIV $1 / 2$ \\
\hline \multirow{2}{*}{ Cancer patients } & $\mathrm{n}$ & $13 / 549$ & $3 / 549$ & $0 / 469$ \\
\cline { 2 - 5 } & $\%$ & 2.4 & 0.6 & 0 \\
\hline \multirow{2}{*}{ Hemodialysis patients } & $\mathrm{n}$ & $6 / 144$ & $2 / 144$ & $0 / 131$ \\
\cline { 2 - 5 } & $\%$ & 2 & 1 & 0 \\
\hline \multirow{3}{*}{ Pregnant women } & $\mathrm{n}$ & $113 / 5885$ & $8 / 5885$ & - \\
\cline { 2 - 5 } & $\%$ & 1.92 & 0.136 & - \\
\hline \multirow{2}{*}{ Diabetics } & $\mathrm{n}$ & $17 / 178$ & $4 / 181$ & $0 / 63$ \\
\cline { 2 - 5 } & $\%$ & 9.5 & 2.2 & 0 \\
\hline \multirow{2}{*}{$\begin{array}{l}\text { HBsAg: Hepatitis B surface antigen, HCV: Hepatitis C virus, HIV: Human } \\
\text { immunodeficiency virus }\end{array}$}
\end{tabular}

\section{Ethics}

Peer-review: External and Internal peer-reviewed.

\section{Authorship Contributions}

Concept: Kerem Yılmaz, Mehmet Köroğlu, Design: M. Koroglu, Mustafa Altındiş, Data Collection or Processing: Tayfur Demiray, Kerem Yılmaz, Analysis or Interpretation: Tayfur Demiray, Kerem Yilmaz

Literature Search: Tayfur Demiray, Mehmet Köroğlu, Writing: Tayfur Demiray, Mehmet Köroğlu, Mustafa Altındiş.

Conflict of Interest: No conflict of interest was declared by the authors.

Financial Disclosure: The authors declared that this study has received no financial support.

\section{References}

1. Ockner RK. Acute Viral Hepatitis. In: Bennett C, Plum F (eds.), Cecil Textbook of Medicine, 20 th ed. Philadelphia: PA: Lippincott Williams \& Wilkins; 1996; p. 765-768.

2. Utkan, G, Azap A, Muallaoğlu S, Tokluoğlu S, Durnalı AG, Arslan ÜY, Koçer M, Çelenkoğlu G, Akbulut H, Alkış N. Hepatitis B and C Seroprevalence in Cancer Patients: A Case Control Study. UHOD 2006;16:103-107.

3. Aynığlu A, Aynıŏlu O, Akar T, Aydın M, Altınok ES. HBsAg, Anti-HBs and Anti-HCV Seropositivity Rates among Pregnant Women Attending a University Hospital in Zonguldak. Viral Hepatitis Journal 2015;21:31-34.

4. Temiz H, Kaya S, Berekatoglu N, Temiz S, Danıs R. The Evaluation of the Seroprevalence of HBV, HCV and HIV Infections and the Assessment of Antibody Response to Hepatitis B Vaccination in Hemodialysis Patients. Viral Hepatitis Journal 2013;19:140143.

5. Orbay E, Bayramicli OU,Kılıc D, Kavaklı B, Yayla A. The Seroprevelance of Hepatitis B and Hepatitis C Infection in Patients with Diabetes Mellitus (Turkish). Türk Aile Hek Derg 2002;6:105-109. 